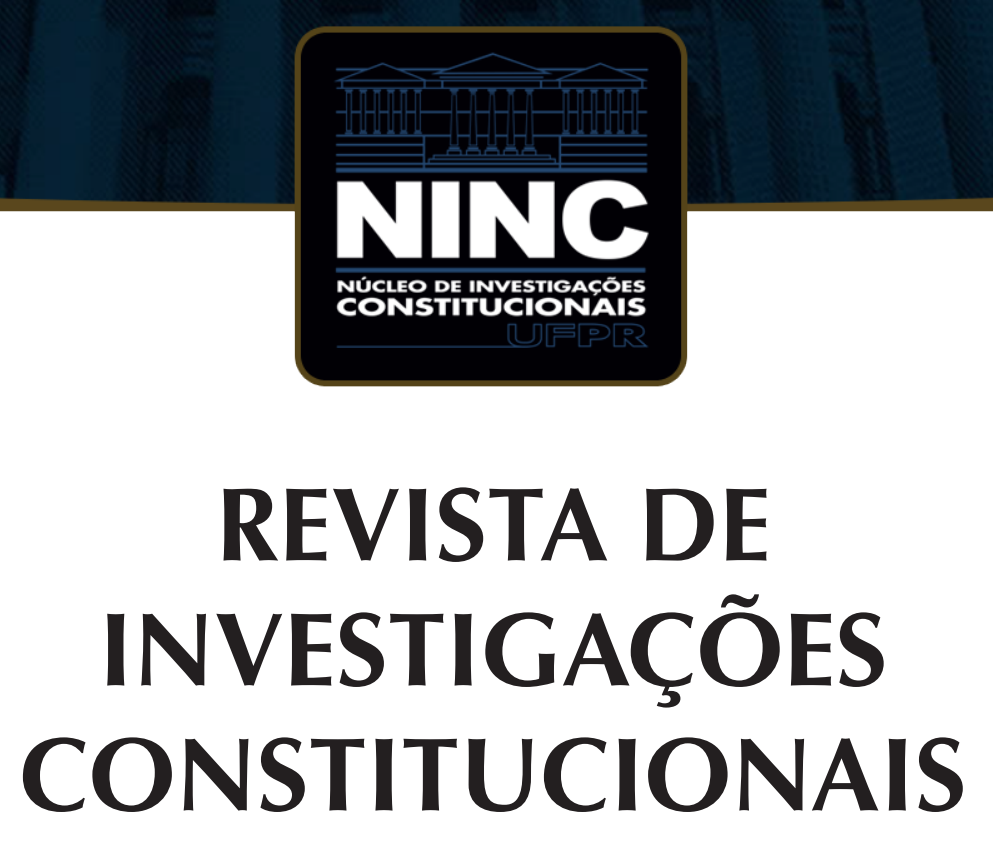

JOURNAL OF CONSTITUTIONAL RESEARCH

vol. 7 | n. 3 | setembro/dezembro 2020 | ISSN 2359-5639 | Periodicidade quadrimestral Curitiba | Núcleo de Investigações Constitucionais da UFPR | www.ninc.com.br 


\title{
Constitutional amendments' theory and troubles at supranational level: Constitutional change in the EU from the perspective of Richard Albert's analysis
}

\section{Teoria das emendas constitucionais e problemas a nível supranacional: alteração constitucional nos EUA a partir da perspectiva de análise de Richard Albert}

\author{
CRISTINA FASONE ${ }^{1, *}$ \\ ' Libera Università Internazionale degli Studi Sociali Guido Carli - LUISS (Rome, Italy) \\ cfasone@luiss.it \\ http://orcid.org/0000-0002-8426-8797 \\ Recebido/Received: 30.06 .2020 / June $30^{\text {th }}, 2020$ \\ Aprovado/Approved: 02.11.2020 / November 2 ${ }^{\text {nd }}, 2019$
}

\begin{abstract}
Richard Albert's book offers a crucial systematization of constitutional amendments, their forms, procedures and scope. In doing so, it provides important insights on the theory and the practice of constitutional amendment design, the difficulty they face and the varieties of unamendability, amongst other things. This contribution seeks to apply Richard Albert's analysis to the case of the European Union, where the existence of a fully-fledged Constitution has long been contested. It claims that this analytical framework can help to better understand the functioning of EU "constitutional amendments", i.e. Treaty revisions, and their limits, in a context where they have remained substantially understudied.
\end{abstract}

Keywords: constitutional amendments; European Union; European Treaty revisions; unamendability; overcostituzionalization

\section{Resumo}

O livro de Richard Albert oferece uma sistematização crucial das emendas constitucionais, suas formas, procedimentos e escopo. Ao fazer isso, são previstos importantes insights na teoria e na prática do desenho das emendas constitucionais, as dificuldades que encontram, as variações de inamendabilidade, entre outras coisas. Esta contribuição busca aplicar a análise de Richard Albert para o caso da União Europeia, onde a existência de uma Constituição integral tem sido contestada. Esta análise pode ajudar no melhor entendimento das emendas constitucionais da UE, ou seja, das revisões de Tratados de seus limites, num contexto em que essas não têm sido suficientemente estudadas.

Palavras-chave: emendas constitucionais; União Europeia; revisões de Tratados Europeus; inamendabilidade; superconstitucionalização.

Como citar esse artigo/How to cite this article: FASONE, Cristina. Constitutional amendments' theory and troubles at supranational level: Constitutional change in the EU from the perspective of Richard Albert's analysis. Revista de Investigações Constitucionais, Curitiba, vol. 7, n. 3, p. 707-732, set./dez. 2020. DOI: 10.5380/rinc.v7i3.74848.

*Assistant Professor of Comparative Public Law at Libera Università Internazionale degli Studi Sociali Guido Carli - LUISS (Rome, Italy). E-mail: cfasone@luiss.it. 


\section{CONTENTS}

1. Introduction; 2. The comparability of the EU "Constitution"; 3. The fragmented constitutional constellation of the EU; 3.1. The "overconstituzionalization" of EU law; 3.2. Norms that are constitutional in nature but are not part of EU primary law; 4. EU "constitutional" amendment procedures and "dismemberments"; 5. Constitutional unamendability in EU law; 6 . References.

\section{INTRODUCTION}

If and to what extent can Richard Albert's book on constitutional amendments provide the ground for assessing and critically review "constitutional amendments" procedures and practice at European Union (EU) level? This contribution argues that the analysis offered by this book, both from a theoretical-conceptual perspective and in terms of concrete choices of forms and design of constitutional amendments' procedures, sheds lights on the weaknesses and pitfalls on how EU law has evolved so far and on the potential direction to take. The topic has recently triggered once again a lively academic debate, on the problem of the overconstitutionalization of EU rules and on the difficulty to revise the Treaties with a view to face the multiple crises the EU is experiencing.

By drawing on the extensive body of scholarship on the nature of the EU and on its comparability with other entities in the international community, this contribution first justifies why it is worth exploring the EU constellation through the lens of a study on constitutional amendments that primarily - though not exclusively ${ }^{1}$ - refers to States. Second, the contribution explores how concepts devised or arguments elaborated in Richard Albert's monograph - including constitutional dismemberment, amendment difficulty and its fallacy and variations of unamendability - apply to EU constitutional changes and help to better understand the legitimacy problems surrounding it.

\section{THE COMPARABILITY OF THE EU “CONSTITUTION"}

Perhaps there is no other academic debate in EU legal studies that has triggered, directly or indirectly, equal share of scholarly attention than the discussion on the constitutional nature of the EU. The reflections on its democratic nature, on sovereignty problems and powers conferred, on the autonomy of EU law, on the Peoples v. the People of Europe dichotomy can all ultimately traced back to "the" big question: does the EU have a Constitution?

As early as in 1986 the European Court of Justice answered positively to this question stating that "the European Economic Community is a Community based on

\footnotetext{
ALBERT, Richard. Constitutional Amendments: Making, Breaking and Changing Constitutions. Oxford: Oxford University Press, 2019, p. 5, 96, 234, 319.
} 
the rule of law, inasmuch as neither its Member States nor its institutions can avoid a review of the question whether the measures adopted by them are in conformity with the basic constitutional Charter, the Treaty (emphasis added)".2 However, the issue is a little bit more complex as the EU has evolved.

Indeed, from a purely international law perspective and according to some recent legal philosophical analyses the EU is nothing more than an international organization. ${ }^{3}$ It does no possess original powers, inherent in its fundamental structures, unlike sovereign entities, but it lives with powers that are conferred through the Treaties (Art. 4TEU) - the Treaty on the European Union, the Treaty on the functioning of the European Union and the Charter of fundamental rights - and that, thus, could be further expanded but also withdrawn. The today's 27 Member States still remain the "masters of the treaties". Neither the EU is a State, the entity for which modern Constitutions were first devised. It does possess a territory with external borders and whose geographical reach is vaguely identified with "Europe" by Article 49 TEU.

More questionable is whether the EU finds it legitimacy in a People. Habermas has repeatedly claimed that there is no unified People in the Union, but that the People could be constructed through deliberation and discourse in the wide European public sphere. ${ }^{4}$ The recognition of the European citizenship to all nationals of the Member States since the Maastricht Treaty (1993) and the (ambivalent) case law of the Court of Justice have not supplemented sufficient substance to the construction of the European (cross-border) citizen. ${ }^{5}$ Just a few rights, mainly political rights, are genuinely attached to the European citizens, while most economic and social rights the EU grants are protected for European citizens as well as for third country nationals resident in one of the Member States. Surveys shown that there is little sense of belonging to a European People (though this might not be very different from what happens in some States with highly divided societies). ${ }^{6}$

The last decade in particular has seen the success of Nikolaïdis' idea of "demoicracy" to describe the Union's system of government: a Union of peoples (plural, as many as the Member States), "understood as both states and citizens, who govern

2 European Court of Justice. Parti écologiste “Les Verts” v. European Parliament. Case C-294/83, ECR 1986 -01339 (Judgment of the Court of 23 Apr. 1986), para. 23.

3 ELEFTHERIADIS, Pavlos. A Union of Peoples. Oxford: Oxford University Press, 2020, p. 3 ff.

4 HABERMAS, Jürgen. Democracy in Europe: Why the development of the EU into a transnational democracy is necessary and how it is possible. European Law Journal, vol. 21, n. 4, p. 546-557, Jul. 2015.

5 AZOULAI, Loïc; BARBOU DES PLACES, Ségolène; PATAUT. Etienne (eds.). Constructing the Person in EU Law: Rights, Roles, Identities. Oxford: Hart Publishing, 2016.

6 O'FLYNN, Ian. Deliberative Democracy and Divided Societies. Edinburgh: Edinburgh University Press, 2006, p. 32 ff. 
together but not as one". ' Controversial as it can be, the "demoicratic" idea reflects a compound constitutional structure where institutions representing the Member States through their governments, the Council and the European Council, coexist with a Parliament directly elected by the peoples(s), through an electoral process that is partly regulated by EU law and partly by domestic law. ${ }^{8}$ In addition to this, there are technical bodies, exercising mainly, though not only, executive powers, like the European Commission and the European Central Bank (ECB), who represent the supranational common interests and whose legitimacy is based on their technical expertise. In relation to them, democratic legitimation is either absent - in the case of the ECB strong forms of democratic accountability could be even dangerous for the fulfillment of its independent mandate - or weak, although the process of appointment of the Commission has been more evidently linked to the European Parliament elections since 2009 (Article 17 TEU). "The lack of the People's argument", however, does not appear as a very convincing objection to deny a constitutional status (modelled around the State conception) to the EU. Comparative federalism, at least, provide several examples of multinational and ethnically divided States, where it is impossible to identify a unified People or where the idea of a People is constructed over decades or centuries and certainly does not predate the specific legal system. ${ }^{9}$

When looking at the third and last constitutive element of a State, according to Jellinek, ${ }^{10}$ sovereignty, it appears at first that it is missing at the EU supranational level. The higher law of the European Union - the Treaties and all the provisions having a primary status - is made and changed through complex procedures that requires the unanimity of the Member States (Article 48 TEU). At present, both the ordinary and the simplified revision procedures set as a requirement the unanimity of the Member States to let a Treaty change enter into force (see further section 4). However, it has been pointed out that once the rules are set in the Treaties, EU law tends to develop autonomously from the Member States and this element would be a sign of a de facto sovereignty conquered by the EU. ${ }^{11}$ The real engine of the European integration, the Court of Justice, from the very beginning has devised structural principles governing the relationship between national law and EU law, like the principles of primacy and

\footnotetext{
NIKOLAÏDIS, Kalypso. European Demoicracy and Its Crisis. Journal of Common Market Studies, vol. 51, n. 2, p. 351-369, mar. 2013.

8 See the European Electoral Act of 1976, as subsequently amended. For an analysis of national legislation on the European elections, see: VIOLA, Donatella Maria (ed.). Routledge Handbook of European Elections. Abingdon: Routledge, 2015.

9 Recent scholarly contributions have also tried to deconstruct the idea of the "sovereign People" and of "peoplehood" as the precondition of the exercise of sovereign powers. See: OKLOPCIC, Zoran. Beyond the People: Social Imaginary and Constituent Imagination. Oxford: Oxford University Press, 2018, p. 44 ff.

10 JELLINEK, George. Allgemeine Staatslehre. 3. ed. Berlin: Häring, 1914, p. 180-181.

11 GRIMM, Dieter. Sovereignty: The Origin and Future of a Political and Legal Concept. New York: Columbia University Press, 2015, p. 99 ff.
} 
direct effect and the decentralized enforcement of EU law, ${ }^{12}$ making national judges and administrations responsible for that, and thereby ensuring an autonomy of action that could not be originally foreseen. Relatedly, although the discourse on sovereignty and constituent power is not perfectly overlapping,,$^{13}$ new narratives have been developed in relation to the constituent power in the EU that do not tend to reduce constitution-making in this context merely to the will of the "Masters of the Treaties", the States ${ }^{\prime 14}$ but - mostly as an aspiration - emphasize bottom-up participation of citizens, as both national and EU citizens, in the exercise of a pouvoir constituant mixte. ${ }^{15}$

It is not by chance that the EU is the main point of observation when looking at the notion of post-sovereign constellation. ${ }^{16}$ And the Brexit saga, dominated by the mantra of "let's take back control", regardless of whether this is really technically possible as the difficulties in achieving first the withdrawal and now an agreement on the future UK-EU partnership show, confirms that the level of European integration reached fundamentally questions both the idea of (fully) sovereign Nation States and of a non-sovereign Union.

Many scholars have highlighted the similarities between the EU and other federal experiences or federalizing processes. Robert Schütze has emphasized the similarities between the today's EU and the US Confederation before the adoption of the 1787 Constitution. ${ }^{17}$ Others have also reflected on the many point of contacts between the EU and Canada ${ }^{18}$ or the EU and Switzerland. ${ }^{19}$

The deepening of the European integration process, the adoption of a Charter of fundamental rights and a gradual clarification of the EU interinstitutional balance ${ }^{20}$ have led most scholars to agree that the EU does have a Constitution, well beyond the

\footnotetext{
12 European Court of Justice. Van Gend en Loos v. Nederlandse Administratie der Belastingen. Case 26/62 (Judgment of the Court of 5 Feb. 1963); European Court of Justice. Costa v. Enel. Case 6/64 (Judgment of the Court of 15 Jul. 1964); European Court of Justice. Amministrazione delle Finanze dello Stato v Simmenthal SpA. Case 106/77 (Judgment of the Court of 9 Mar. 1978).

13 See CÓLON-RÍOS, Joel. Constituent Power and the Law. Oxford: Oxford University Press, 2020, p. 263 ff. showing that constitution-making powers can be subject to the authority and the indications set by the "sovereign".

14 PATBERG, Markus. Challenging the masters of the treaties: Emerging narratives of constituent power in the European Union. Global Constitutionalism, vol. 7, n. 2, p. 263-293, Jul. 2018.

15 PATBERG, Markus. A systematic justification for the EU's pouvoir constituant mixte: Principles of constitutional politics in supranational polities. European Law Journal, vol. 23, n. 6, p. 451-463, Nov. 2017.

16 See: MENÉNDEZ, Agustín José; FOSSUM, John Erik (eds.). Law and Democracy in Neil MacCormick's Legal and Political Theory. New York: Springer, 2011.

17 SCHÜTZE, Robert. From Dual to Cooperative Federalism: The Changing Structure of European Law. Oxford: Oxford University Press, 2009, chapter 1.

18 VERDUN, Amie. The Federal Features of the EU: Lessons from Canada. Politics and Governance, vol. 4, n. 3, p. 100-110, Aug. 2016, p. 100 ff..

19 FABBRINI, Sergio. Which European Union? Europe after the Euro Crisis. Cambridge: Cambridge University Press, 2015, p. 219-256.

20 Since the Court of Justice's decision in the Meroni case, C-9/56, of 13 June 1958.
} 
State vs. non-State rhetoric, although it is a problematic one. ${ }^{21}$ The Constitution of the EU is fragmented. In addition to the Treaty provisions, it is also fed by the Constitutions of the Member States and anchored to international law as confirmed by the reference, respectively, to the common constitutional traditions and to the ECHR in Article 6.3 TEU makes clear. Moreover, the EU constitutional system heavily relies on domestic institutions for its implementation. It is a Constitution of "bits and pieces"22 and the level of fidelity, loyalty and identification that such a fundamental act is normally expected to trigger is rather low or, better, uneven amongst EU citizens, each projecting on that text national aspirations, interests, culture and history. ${ }^{23}$ Nevertheless the Constitution of Europe contains the fundamental elements that according to Article 16 of the 1789 French Declaration of the right of a man and citizen every modern Constitution shall entail: separation of powers, both horizontally (amongst the EU institutions, though this is put in terms of interinstitutional balance) and vertically (in between the EU and the Member States), and the protection of fundamental rights.

While the idea of a Constitution for the EU goes back at least to the 1984 Altiero Spinelli's (failed) project of a Constitutional Treaty, ${ }^{24}$ it is with the Convention who drafted the Treaty establishing a Constitution for Europe that the debate has been revitalized despite the adverse fate of that Treaty. ${ }^{25}$

\section{THE FRAGMENTED CONSTITUTIONAL CONSTELLATION OF THE EU}

EU primary law - what can be equated to EU constitutional law at first sight - is highly fragmented across a variety of sources of law. First of all, the Treaties. The TEU codifies some of the fundamental principles of EU law (the principles of conferral and of loyal cooperation in Art. 4; the principles of subsidiarity and of proportionality in Art.

21 See: WEILER, Joseph H.H. The Constitution of Europe: "Do the new clothes have an emperor?" and other essays on European integration. Cambridge: Cambridge University Press, 1999.

22 CURTIN, Deirdre. The Constitutional Structure of the Union: A Europe of Bits and Pieces. Common Market Law Review, vol. 30, n. 1, p. 17-69, Feb. 1993.

23 ACKERMAN, Bruce. Three Paths to Constitutionalism - and the Crisis of the European Union. British Journal of Political Science, vol. 45, n. 4, p. 705-714, May. 2015, highlights the importance of the cultural dimension when it comes to the problematic EU constitutional pathway. It is problematic especially because it is the result of a convergence and integration process among countries experiencing different pathways in their constitutional transition to democracy.

24 PONZANO, Paolo. The "Spinelli" Treaty of February 1984. Centro di studi sul federalismo - The Federalist Debate, vol. XX, n. 3, Nov. 2007. Available at: <http://www.federalist-debate.org/index.php/component/k2/ item/282-the-spinelli-treaty-of-february-1984>.

25 WEILER, Joseph H.H. On the power of the Word: Europe's constitutional iconography. International Journal of Constitutional Law, n. 2 \& 3, p. 173-190, May 2005; ELEFTHERIADIS, Pavlos. The Idea of a European Constitution. Oxford Journal of Legal Studies, vol. 27, n. 1, p. 1-21, Spr. 2007; CRUM, Ben. Learning from the EU Constitutional Treaty: Democratic constitutionalization beyond the Nation-State. Abingdon: Routledge, 2011. 
5), fixes the composition and the main tasks of the EU institutions, sets the procedures for amending the Treaties (Art. 48) and contains provisions on common foreign and security policy, on the defence policy as well as on social policy, the least integrated areas in EU law.

The TFEU regulates all (the other) EU internal and external policies in great detail and the procedures to be followed and the acts to be adopted in each field. The Charter of fundamental rights is the EU long "bill of rights" codified, first in 1999 in a Convention, proclaimed twice in 2000 and in 2007 (slightly amended), and eventually entered into force in 2009. To some extent the Charter has put into the higher law of the Union the long-standing case law of the Court of Justice, while other rights, especially the articulated catalogue of social rights, has been added; rights that should be given as much as possible an interpretation consistent with the constitutional traditions common to the Member States and with the ECHR and are nevertheless enforceable, in theory, only when they fall under the scope of application of EU law.

In addition to this, also the 37 Protocols annexed to the Treaties form part of EU primary law and their content ranges from the entrenchment of the Statutes of the Court of Justice (no. 3), of the European System of Central Banks and of the ECB (no. 4), to the privileges and the immunities of the EU (no. 7); from the excessive deficit procedure (no. 12) and the convergence criteria (no. 13) to the provisions on the Schengen acquis (no. 19) and the selective enforcement of specific Treaties' provisions to certain countries (nos. 21, 22 and 30); from the system of public broadcasting in the Member States (no. 29) to the imports of petroleum products refined in the Netherlands Anthilles into the Union (no. 31).

General principles of EU law established by the Court of Justice, even when not codified in the Treaties, like the crucial principle of primacy, ${ }^{26}$ are part of the primary law, too. That said, the area of law that is primary or, by contrast, that is not, in terms of the hierarchy of the sources of law, is a bit blurred. For example, the European Electoral Act and the Decision on the Union's own resources, like every act to be adopted by unanimity in the Council and approved by every Member State according to the domestic constitutional requirements, seem to have a primary status. ${ }^{27}$ However, looking at the legal bases for their adoption in the Treaties (in the examples made, Arts. 223 and 311 TFEU), the relevant procedure is described as a special legislative procedure. Whether the legislative nature of the procedure affects the rank of the legal source in the hierarchy of EU norms, thereby lowering its status to secondary law, remains to be determined and the Court of Justice was never given an opportunity to reflect on that.

\footnotetext{
26 At present, outlined just in Declaration $n^{\circ} 17$ to the Treaties, which is a political and non-binding act.

27 PICCIRILLI, Giovanni. La clausola di sbarramento per le elezioni europee tra Corte costituzionale e principi comuni a tutti gli Stati membri. Studium Iuris, vol. 12, p. 1430-1437, 2019.
} 
Not everyone agrees on the usefulness of the categorization of the EU sources of law along a formal hierarchy of EU norms and for good reasons. ${ }^{28}$ Indeed, when looking carefully at what is inside and what remains outside EU primary law, one clearly understands that, on the one hand, there are many EU primary law provisions that are not constitutional in substance. On the other hand, there are legal sources which certainly have a constitutional pedigree, but that are not included in the formal EU primary law. This asymmetry between formal constitutional hierarchy and the substantive part of a Constitution is rightly emphasized in Richard Albert's book and it certainly applies to the EU. ${ }^{29}$ There is an important difference between having a constitutional amendment only in name or, rather, a constitutional amendment in its real meaning. Looking at the confusion present in the Union, Richard Albert's claims about the importance of reconciling procedure and form with substance of constitutional amendments could be fruitfully followed also in the EU, though with some caveats due to the nature of this legal system that will be explained shortly.

\subsection{The "overconstituzionalization" of EU law}

The legal construction of Europe was effectively channeled from a doctrinal perspective by the "integration through law" project. Conducted under the leadership of Mauro Cappelletti at the European University Institute in Florence in the 1970s and in the 1980 s and supported by a wide range of legal academics, Community civil servants and European judges, this project has provided a constitutional vision to the process of European integration solidly grounded by law. ${ }^{30}$ Law was understood as the main tool through which integration could be constructed, the dominant force giving shape to the common, then, internal market and to its social dimension. ${ }^{31}$ As such there was, and probably, there is still an imbalance in the influence of law as a discipline compared to other social sciences in the European integration. However, how much of this law is constitutional in nature?

\footnotetext{
28 See the work carried out in the framework of the Convention on the future of Europe and, in particular, LENAERTS, Koen. How to Simplify the Instruments of the Union. The European Convention - Working Group IX, Working Document 07, 6 Nov. 2002.

29 ALBERT, Richard. Constitutional Amendments: Making, Breaking and Changing Constitutions. Oxford: Oxford University Press, 2019, p. 268-271.

30 See, notably, PESCATORE, Pierre. Le droit de l'integration. Emergence d'un phénomène nouveau dans les relations Internationales selon l'expérience des Communautés Européennes. Genève: A.W. Sijthoff, Leiden/Institut Universitaire de Hautes Etudes Internationales, 1972. On the main tenets of that project see now BYBERG, Rebekka. The History of the Integration Through Law Project: Creating the Academic Expression of a Constitutional Legal Vision for Europe. German Law Journal, vol. 18, n. 6, p. 1531-1556, Nov. 2017.

31 VAUCHEZ, Antoine. L'union par le droit: L'invention d'un programme institutionnel pour l'Europe. Paris: Sciences Po Les Presses, 2013; AZOULAI, Loïc. "Integration through law" and us. International Journal of Constitutional Law, vol. 14, n. 2, p. 449-463, Apr. 2016.
} 
EU policies are heavily regulated, not just by EU legislation (Art. 289 TFEU (Art. 290 TFEU) and by implementing acts (Art. 291 TFEU), the latter comprising by far the greatest part of the legal acts adopted every year in the EU context. This normative hypertrophy is also evident from the Treaties. Combined together the TEU, the TFEU and the Charter (and Protocols) contain more than 500 articles; an impressive number even compared to the Constitution of India, which is well-known for being the longest Constitution in the world. However, as Richard Albert rightly points out in his book, it is not just a matter of quantity. ${ }^{32}$ Also the quality of the constitutional drafting matters and EU primary law provisions, especially in the TFEU, are very detailed and include many norms - procedural and substantive, with their respective exceptions - that at national level would be contained in ordinary legislation at best. Dieter Grimm has defined this "capture" of ordinary provisions into the EU constitutional texts as the problem of "overconstitutionalization" of the EU. ${ }^{33}$ EU Treaties, in other words, are exactly the opposite of how a constitutional text is expected to be drafted, i.e. as an "Incomplete Code". ${ }^{34}$ Filling the text of the treaties of provisions that in theory are all but constitutional in their content, on the one hand, is functional as a risk-sharing mechanism: the limited mutual trust amongst the Member States, amplified by multilingualism and by the progressive expansion and deepening of the EU integration process, finds in the "overconstitutionalisation" an effective reassurance tool. Those provisions, indeed, cannot be modified without the agreement of all the contracting parties in principle. To de-constitutionalize them, instead, would mean to open the door to legislation that can be adopted and amended with qualified majorities..$^{35}$

On the other hand, however, "overconstitutionalization" creates a legitimacy problem because in the case of the EU triggers a de-politicization of the decision-making. Once the discipline of a certain subject-matter is entrenched in the treaties it is almost impossible to modify it, given the Treaty amendment procedures. Due to the "overconstitutionalization", this resistance to change applies also to issues that would be normally subject - outside the EU - to lower lawmaking but that in the Union are thus de facto "immunized" against public pressure and political correction. ${ }^{36}$ Against this backdrop and the "original sin" of European treaties going beyond the core functions national

\footnotetext{
32 ALBERT, Richard. Constitutional Amendments: Making, Breaking and Changing Constitutions. Oxford: Oxford University Press, 2019, p. $261 \mathrm{ff}$.

33 GRIMM, Dieter. The Democratic Costs of Constitutionalisation: The European Case. European Law Journal, vol. 21, n. 4, p. 460-473, May. 2015.

34 ALBERT, Richard. Constitutional Amendments: Making, Breaking and Changing Constitutions. Oxford: Oxford University Press, 2019, p. 22-24

35 At present qualified majority voting in the Council requests to meet two conditions at the same time: $55 \%$ of EU countries vote in favour representing at least $65 \%$ of the total EU population.

36 GRIMM, Dieter. The Democratic Costs of Constitutionalisation: The European Case. European Law Journal, vol. 21, n. 4, p. 460-473, May. 2015, p. 460.
} 
constitutions typically fulfil, it has been suggested that the "de-constitutionalization" of EU law would entail a strengthened role for EU political institutions, in particular the Council and the Parliament, and a different use of the majority rule: both to authorize the selective disapplication of EU norms by Member States in areas covered by simple or qualified majority voting and to stop such a selective disapplication - in case it turns into free riding - by special majorities in the Council and in the European Parliament. ${ }^{37}$ By playing with the majority rule more flexibility would be ensured.

\subsection{Norms that are constitutional in nature but are not part of EU pri- mary law}

While the EU treaties are full of provisions that are at odd with the usual contents of domestic Constitutions, there are many EU norms that appears as constitutional in nature - in that they affect the interinstitutional balance, the relationship between the Union and the Member States and well as fundamental rights - but are not entrenched into primary law.

These constitutional norms are, for example, those provided in the interinstitutional agreements between the European Parliament, the Commission and the Council: "common agreement[s]" through which they "make arrangement for their cooperation" and that "may be of a binding nature" (Art. 295 TFEU). The scope of these interinstitutional agreements ranges from joint programming activities, tools for better law-making, transparency and accountability to the citizens ${ }^{38}$ to the exercise of budgetary powers in the Union. ${ }^{39}$ While the status of these agreements has never been clarified by the Court of Justice, some have argued that, given their content and the way they are formed (by consolidating existing practices) they amount to "constitutional conventions" in the EU. $^{40}$

In addition to this, there are sources of law like inter se agreements concluded among some or all Member States which are not strictly speaking EU norms and that

\footnotetext{
37 SCHARPF, Fritz W. De-constitutionalisation and majority rule: A democratic vision for Europe. European Law Journal, vol. 23, n. 5, p. 330-332, Nov. 2017.

38 See the Interinstitutional Agreement on Better Law-Making of 13 April 2016, OJEU L123/1, 12.5.2016.

39 See the Interinstitutional Agreement on budgetary discipline, on cooperation in budgetary matters and on sound financial management of 2 December 2013, OJEU C373/1, 20.12.2013 and the Interinstitutional Agreements adopting the Multiannual Financial Framework, the long term (7 year) budget of the EU.

40 BEUKERS, Thomas. Law, Practice and Convention in the Constitution of the European Union. Amsterdam, 2011. 419 p. Thesis (PhD) - Faculty of Law, University of Amsterdam, p. 201-290; IBRIDO, Renato; LUPO, Nicola. Introduzione. "Forma di governo" e "indirizzo politico": la discussa applicabilità all'Unione europea. In: IBRIDO, Renato; LUPO, Nicola (eds.). Dinamiche della forma di governo tra Unione europea e Stati membri. Bologna, II Mulino, 2018. ft. 25.
} 
nevertheless constitute a significant part of the European "Constitution".41 These "quasi-instruments of EU law", as they have been described, define constitutional aspects of the life of the Union. For example, the Schengen Agreement of 1985, subsequently incorporated into EU law in 1997 with the Treaty of Amsterdam, regulates the status of the EU citizens, their free movement across the Member States, and, relatedly it also protects third country nationals once they have entered the EU (in any of the Member States applying the Schengen acquis). In 2012 the Treaty on stability, economic coordination and governance in the Economic and Monetary Union (TSCG), signed by all Member States but the UK and the Czech Republic back then, ${ }^{42}$ sets important rules on fiscal discipline for the entire Union and especially for the countries adopting the euro as the single currency. To some extent it designs the "Economic Constitution" 43 of the EU without being formally part of it. ${ }^{44}$

By the same token, also national constitutional clauses, more or less directly, shape European constitutional law. On the one hand, national participation in the EU integration process is grounded in the Member States' Constitutions through ad hoc clauses in many cases (see Art. 23 of the German Basic Law) or in general clauses authorizing the limitation of the country's sovereignty in favour of international organizations. ${ }^{45}$ Moreover, as Richard Albert points out, drawing on the Spanish case and on new Art. 135 of the national Constitution, ${ }^{46}$ the national fundamental laws are full of references to EU law and, by doing so, they provide a crucial vehicle for the enforcement of the EU Constitution.

On the other hand, the case law of the Court of Justice, first, ${ }^{47}$ and then the Treaty themselves (see now Art. 6 TEU) refer to the constitutional traditions common to the Member States as constitutional standards for the interpretation of EU law. The relationship between EU law and national constitutional law is to a large extent osmotic or,

41 DE WITTE, Bruno; MARTINELLI, Thibaud. Treaties between EU Member States as Quasi-Instruments of EU Law. In: CREMONA, Marise and KILPATRICK, Claire (eds). EU Legal Acts: Challenges and Transformations. Oxford: Oxford University Press, 2018, p. 158-188.

42 The Czech Republic subsequently signed this Treaty in 2019, while the UK, as well-know, left the EU on 1 February 2020.

43 See: GERAPETRITIS, George. New Economic Constitutionalism in Europe. Oxford: Hart Publishing, 2019.

44 Its incorporation into EU law is foreseen by Art. 16 within five years since its entry into force. The deadline has expired already, but no measure has been taken.

45 CLAES, Monica. Constitutionalizing Europe at its Source: The 'European Clauses' in the National Constitutions: Evolution and Typology. Yearbook of European Law, vol. 24, n. 1, p. 81-125, Nov. 2005.

46 ALBERT, Richard. Constitutional Amendments: Making, Breaking and Changing Constitutions. Oxford: Oxford University Press, 2019, p. 5.

47 Since the Court of Justice famous decision in: European Court of Justice. Internationale Handelsgesellschaft mbH v. Einfuhr- und Vorratsstelle für Getreide und Futtermittel. Case 11/10 (Judgment of the Court of 17 Dec. 1970). 
as has been claimed, they shape together a composite constitutional system, ${ }^{48}$ where it is difficult to kept separate the purely domestic and purely supranational elements. Especially when the EU (the Community) was devoid of its own catalogue of fundamental rights the reference to common constitutional traditions has been crucial to "translate" rights protected under domestic Constitution into the European realm. ${ }^{49}$ The long-lasting influence of the "common constitutional traditions" discourse has been confirmed also recently despite the EU enlargement and the success, particularly in some Member States, of the "constitutional identity" narrative, which tends to highlight national specificities rather than transnational commonalities..$^{50}$

The richness of the EU constitutional constellation, also fed by EU sources of law that are not comprised into primary law or by sources that formally do not stem from the Union, helps to clarify why constitutional amendments and unamendability in this supranational context are difficult to be systematized, even from a conceptual level, and why Richard Albert's book can be inspiring (also) from this perspective.

\section{EU “CONSTITUTIONAL" AMENDMENT PROCEDURES AND “DIS- MEMBERMENTS"}

To start with, amendments to EU primary law can be mainly catalogued through the "integrative model" articulated by Richard Albert: EU "constitutional amendments" are directly integrated "into the text of the original master text constitution".51 Once inserted into EU primary law, within the consolidated text of the Treaties, amendments are no longer detectable. There is no reference to when, how and how many times a particular provision has been changed. The only sign of a previous version of a certain treaty article is the indication of the old numbering of that article in brackets. That said the Reform Treaty that brought about the "constitutional amendments", published on the EU Official Journal, remains there to signify and make available to the public the list of changes that once were adopted, even though it is the consolidated version of the treaties that is regularly consulted and used.

In some respect also the "disaggregative model" of constitutional amendments, which do not appear in a single codified constitutional document and referred by

48 BESSELINK, Leonard F.M. A Composite European Constitution. Amsterdam: Europa Publishing, 2007.

49 See, notably, the decision of the Court of Justice in: European Court of Justice. Internationale Handelsgesellschaft mbH v. Einfuhr - und Vorratsstelle für Getreide und Futtermittel. Case 36/02 (Judgment of the Court of 14 Oct. 2004), where the case was solved drawing on the German Basic Law and on the protection of human dignity, a right shared by all national constitutions of the Member States.

50 FICHERA, Massimo; POLLICINO, Oreste. The Dialectics Between Constitutional Identity and Common Constitutional Traditions: Which Language for Cooperative Constitutionalism in Europe?. German Law Journal, vol. 20, n. 8, p. 1097-1118, Dec. 2019.

51 ALBERT, Richard. Constitutional Amendments: Making, Breaking and Changing Constitutions. Oxford: Oxford University Press, 2019, p. 236. 
Richard Albert mainly to the Constitutions of Israel, New Zealand and UK, 52 may come into play in the EU context. As described in section 3, within the varied constellation of EU "constitutional norms", in addition to Treaty provisions, intergovernmental agreements, constitutional conventions, codes of conduct and legislative acts of constitutional significance (like the Electoral Act) can be included. Therefore, also the modification of one of these sources can be considered as a "disaggregative" constitutional change.

Since the entry into force of the Treaty of Lisbon, in 2009, two types of procedures are envisaged to reform the Treaties (Art. 48 TEU). The ordinary revision procedure, "enriched" compared to the pre-Lisbon version, foresees as the starting point a decision of the European Council, by simple majority and after having consulted the Parliament and the Commission. Within the ordinary revision procedure two options are available: the default option is the summoning by the President of the European Council of a Convention "composed of representatives of the national Parliaments, of the Heads of State or Government of the Member States, of the European Parliament and of the Commission" while the ECB can be consulted if the proposed changes affect monetary policy (Art. 48, par. 3 TEU). In theory this Convention is only asked to examine the proposed amendments and to adopt by consensus a recommendation to a conference of representatives of national governments that determines "by common accord the amendments to be made to the Treaties" (Art. 48, par. 4 TEU). The subordinated option, instead, allows the European Council, by simple majority and with the consent of the European Parliament, to waive the requirement to establish a Convention whenever the scope of the change does not justify the setting up of this ad hoc body, which is costly and makes the process longer but is expected to grant a more solid democratic underpinning to the Treaty change. In these circumstances, it is the European Council that defines the mandate of the intergovernmental conference.

Interestingly, none of these ordinary procedures has been used since 2009. The procedure leading to the setting up of the Convention, although Art. 48 TEU does not clarify with which proportion the different institutions involved have to be represented, is a codification of the practice followed when the Charter of fundamental rights and the Constitutional Treaty were drafted. On those occasions, as to strengthen the democratic commitment of the constitution-making exercise, members of parliaments, especially from national parliaments, were in a majority. ${ }^{53}$ Moreover, the Conventions worked for more than one year each, in public and in a transparent manner, "as if" they were to draft and agree on the Treaty amendments nor just to issue recommendations

52 ALBERT, Richard. Constitutional Amendments: Making, Breaking and Changing Constitutions. Oxford: Oxford University Press, 2019, p. 234

53 MANZELLA, Andrea. The convention: a new model for constitution-making. In: Europeos (ed.). Institutional reforms in the European Union. Rome: Europeos, 2002. p. 159-182. 
to the intergovernmental conferences, which found themselves with tied hands when deciding on the Conventions' proposals. ${ }^{54}$

While the history of the European integration has known just two Conventions, both organized before they were codified as the ordinary method for Treaty changes, all treaty revisions have featured the crucial work and deliberation of an intergovernmental conference, working behind closed doors. The secrecy of the constitution-making process, particularly with the gradual increase of the Member States, was key to make the process smooth. Indeed, intergovernmental conferences have normally ensured a deal on Treaty amendments within a few months, in preparation of the much longer ratification stage.

In fact, what has proved to be very cumbersome in the process of adoption of EU "constitutional amendments" is the second stage, the national one, after the reform treaty has been signed: "The amendments shall enter into force after being ratified by all the Member States in accordance with their respective constitutional requirements (Art. 48, par 4 TEU)." As has been the case during the "season" of Treaty changes, from the Single European Act of 1987 until the Lisbon Treaty, the failure - with the Constitutional Treaty - or the delay in the entry into force of Treaty revisions was due to the national constitutional requirements set in combination with the unanimity rule. ${ }^{55} \mathrm{Re}-$ ferendums - mandatory or optional - held in some Member States, namely Denmark, France, Ireland, the Netherlands have seriously challenged the possibility to achieve a successful ratification in these countries, with implications for the whole EU. By the same token, the judgments of some Constitutional and Supreme Courts on the ex ante review of the constitutionality of the Treaty revisions or of the domestic norms for their ratification and implementation have been awaited with some concerns. ${ }^{56}$ In the event of a conflict, either the country cannot ratify the treaty change, thereby leading to an European impasse, or the national Constitution has to be changed (as it regularly occurs in Ireland).

54 On the Convention method, see DELOCHE-GAUDEZ, Florence. La Convention européenne sur l'avenir de l'Europe: ruptures et continuités. In: AMATO, Giuliano; BRIBOSIA, Emmanuelle and DE WITTE, Bruno (eds.). Genèse et destinée de la Constitution européenne: commentaire du traité établissant une Constitution pour l'Europe à la lumière des travaux préparatoires et perspectives d'avenir. Bruxelles: Bruylant, 2007. p. 47-85 and PINELLI, Cesare. The Convention Method. In: LUPO, Nicola; FASONE, Cristina (eds.). Interparliamentary Cooperation in the Composite European Constitution. Oxford-Portland: Hart Publishing, 2016. p. 57-72. Changes were nevertheless introduced by the intergovernmental conferences both on the Charter and on the constitutional Treaty.

55 Although Article 48, para 5 TEU leaves the door open to bypass the unanimity requirement under the ordinary revision procedure, potentially: "If, two years after the signature of a treaty amending the Treaties, four fifths of the Member States have ratified it and one or more Member States have encountered difficulties in proceeding with ratification, the matter shall be referred to the European Council". See: CLOSA, Carlos. The Politics of Ratification of EU Treaties. Abingdon: Routledge, 2013, p. 30-39.

56 German Constitutional Tribunal, Second Senate. Judgment on the Treaty of Lisbon and the related acts of approval and implementation. 2 BvE 2/08 (Judgment of the Court of 30 Jun. 2009). 
This problem can be bypassed, should one of the simplified revision procedures, introduced by the Lisbon Treaty, be followed. Under Art. 48, par. 6 TEU Part Three of the TFEU, on the EU internal policies and actions, can be modified in its entirety or just some clauses. Such a procedure, however, cannot entail an increase in the Union's competences (unlike the ordinary revision procedure). In this case, the Treaty amendment is agreed directly in the European Council by unanimity, after consulting the Parliament and the Council as well as the ECB, if the monetary policy is concerned. The European Council decision enters into force only if approved by the Member States according to national constitutional requirements. By not mentioning the ratification, but just the approval, Art. 48, par. 6 TEU was thought of making the entry into force smoother than with the ordinary revision procedure. However, the only case when this procedure was used to date, in 2011, to modify Art. 136 TFEU and create a permanent fund, the European Stability Mechanism (ESM) financed by national budgets to rescue Eurozone countries in need of financial assistance, has shown that this expectation was wrong. The approval of the European Council Decision 2011/199/EU has been challenged in front of domestic courts and has even reached the Court of Justice of the EU (see section 5). ${ }^{57}$

The second simplified revision procedure, never applied so far, consists in activating the so-called "passerelle clauses", only in limited circumstances (art. 48, par. 7 TEU). Notably to shift from unanimity rule to qualified majority rule in the Council, whenever the TFEU or Title $V$ of the TEU provides for unanimity, and to shift from a special legislative procedure (which normally assigns to the Council a central stage) to the ordinary legislative procedure (where the Parliament and the Council act on an equal footing) when the TFEU prescribes the special legislative procedure. Thus "passerelle clauses" are meant, on the one hand, to ease the adoption of an act and, on the other, to make it more democratic by including the Parliament as a real decision-maker. For this to happen the European Council shall act by unanimity, after the Parliament has given its consent by a majority of its members. In addition to this, the initiative of the European Council is notified to the 27 national parliaments that within six months can notify their opposition. The European Council's Decision is eventually adopted only if no objection has been raised by any of the national parliaments.

It follows that also for the simplified revision procedures the unanimity requirement for Treaty amendments is confirmed and, in any event, any constitutional change in the EU has to go through a European and a national stage. Linked to this discourse is the problem of the constitutional amendment difficulty in the EU.

57 GRANAT, Katarzyna. Approval of Article 136 TFEU Amendment in Poland: The Perspective of the Constitutional Court on Eurozone Crisis law. European Public Law, vol. 21, n. 1, p. 31-46, Feb. 2015; BARDUTZKY, Samo. Constitutional Courts, Preliminary Rulings and the "New Form of Law": The Adjudication of the European Stability Mechanism. German Law Journal, vol. 16, n. 6, p. 1771-1790, Mar. 2015, who highlights that very often the constitutional challenges against the European Council Decision 2011/199/EU have been combined to those against the Treaty on the ESM. 
As Richard Albert observes, despite the very high threshold for agreeing on Treaty changes, in the course of the European integration process amendments have been rather frequent. "One might think that building consensus among a multinational body of nearly thirty countries in the European Union would be more difficult than meeting the unanimity threshold among thirteen states under the Articles of Confederation. And yet the Treaties of the European Union have been amended many times, ${ }^{58}$ more frequently than the Articles, which have fewer veto players and a lower denominator".59 Indeed, in between 1987 and 2009 a "semi-permanent Treaty revision process"60 has been witnessed: in about thirty years 6 reform treaties and a Charter of fundamental rights have been drafted, plus 4 accession Treaties, which also modify certain treaty provisions (for example on the composition of the institutions). ${ }^{61}$ What is remarkable is not just the number of subsequent treaties, but also the scope of the changes they brought about. The founding treaties were changed extensively, reform after reform, for what concerns the institutional architectures, the EU competences and policies and fundamental rights, adding a series of details that are unusual in the drafting of constitutional texts (see section 3). For some decades the continuous process of Treaty change was probably favoured by the spillover effects of the end of the Cold War and the German reunification and by a consensual mode of operation within and among the EU institutions and the Member States targeting the idea of "an ever closer Union". By 2005, however, when the people in two founding Member States, France and the Netherlands, rejected the Constitutional Treaty at the referendums, and following the accession of 12 new countries from the Eastern bloc, the "permissive consensus" 62 had gone.

The present situation in the Union is that of an impasse with regard to Treaty revisions, while the Eurozone crisis, the refugee crisis, Brexit, the rule of law problems and now the pandemic have revealed that the EU is in desperate need for a reform. Deeply divided internally and with limited public support, the EU institutions have tried to

58 PEERS, Steve. The Future of EU Treaty Amendments. Yearbook of European Law, vol. 31, n. 1, p. 19-22, Apr. 2012.

59 ALBERT, Richard. Constitutional Amendments: Making, Breaking and Changing Constitutions. Oxford: Oxford University Press, 2019, p. 96.

60 DE WITTE, Bruno. The Closest Thing to a Constitutional Conversation in Europe: The Semi-Permanent Treaty Revision Process. In: BEAUMONT, Paul, LYONS, Carole and WALKER, Neil (eds.). Convergence and Divergence in European Public Law. Oxford-Portland: Hart Publishing, 2002, p. 39.

61 Reform Treaties were, in order, the Single European Act, the Treaty of Maastricht, the Treaty of Amsterdam, the Treaty of Nice and the Charter of fundamental rights (the latter proclaimed but not entered into force until 2009), the Constitutional Treaty (failed), and the Treaty of Lisbon. The accession treaties, instead, were those concerning Norway, Austria, Finland and Sweden (1994), concerning Cyprus, Czech Republic, Estonia, Hungary, Latvia, Lithuania, Malta, Poland, Slovakia, Slovenia (2003), concerning Bulgaria and Romania (2005), and concerning Croatia (2011).

62 HOOGHE, Liesbet and MARKS, Gary. A Postfunctionalist Theory of European Integration: From Permissive Consensus to Constraining Dissensus. British Journal of Political Science, vol. 39, n. 1, p. 1-23, Jan. 2009. 
launch a new process of reflection about Treaty changes, through a Conference on the Future of Europe expected to start to work in Fall 2020. The composition does not appear very different from a Convention under Art. 48 TEU, but it is devoid of any clear mandate in relation to the discussion of Treaty amendments and its structure has already led to allegations about the lack of people's involvement in the process, being thought as a top-down exercise. ${ }^{63}$ It is the usual criticism emerging every time Treaties are changed due to the limited democratic credentials of the revision procedures, taking into account the detachment or disconnection between EU citizens and EU institutions. ${ }^{64}$

However successful the experience of the Conference on the Future of Europe can be, it appears that the situation in the Union is now quite closed to that described by Richard Albert as "constructive unamendability". In the present political, social and economic circumstances "the codified thresholds required to amend (...) [the treaties] are so onerous that reformers cannot realistically (though they could theoretically) satisfy the standard. What results is the impossibility of amending the rule, even though formally it is amendable".65

Over the last few years, this constitutional amendment difficulty in the EU has triggered the emergence of something close to a "constitutional dismemberment" transformative change with consequences far greater than an amendment - according to some readings of these occurrences. For example, the impossibility to reach unanimity for a Treaty change that would have introduced the obligation for Member States to respect a structural balanced budget has led all EU countries but the Czech Republic and the UK to sign already evoked TSCG, so to formally resort to international law. This is not strictly prohibited under EU law and the Court of Justice in any event could have been involved in principle in reviewing its compatibility with the Treaties. Moreover, the problem the TSCG triggers is not about the content of what it prescribes. Rather, questionable is the precedent it creates, in allowing to bypass the ordinary or simplified Treaty revision procedures whenever their standards are too difficult to meet. ${ }^{67}$ Indeed, the TSCG also sets its own rules for the entry into force, not just moving away from unanimity, but clearly identifying at least two clusters of countries, within and outside the Eurozone, for the sake of the ratification. Art. 15, par. 2 of the TSCG states that the Treaty,

${ }^{63}$ ALEMANNO, Alberto. Europe's Democracy Challenge: Citizen Participation in and Beyond Elections. German Law Journal, vol. 21, Special Issue n. 1, p. 35-40, Jan. 2020.

64 LINDSETH, Peter L. Power and Legitimacy: Reconciling Europe and the Nation State. Oxford: Oxford University Press, 2010, p. 234.

65 ALBERT, Richard. Constitutional Amendments: Making, Breaking and Changing Constitutions. Oxford: Oxford University Press, 2019, p. 158.

66 ALBERT, Richard. Constitutional Amendments: Making, Breaking and Changing Constitutions. Oxford: Oxford University Press, 2019, p. 78.

67 In the European Court of Justice. Defrenne v Sabena. Case 43/75 (Judgment of the Court of 8 Apr. 1976), the Court of Justice had clarified that the EU Treaties can only be modified through the revision procedure provided for by the Treaties themselves. 
agreed in 2012, enters into force on 1 January 2013 "provided that twelve Contracting Parties whose currency is the euro have deposited their instrument of ratification, or on the first day of the month following the deposit of the twelfth instrument of ratification by a Contracting Party whose currency is the euro, whichever is the earlier". Considering that in 2012 the EU Member States were 27 and 17 where the Eurozone countries the 12-ratification threshold is considerably lower than the usual EU one. Moreover, the TSCG devalues the weight of the ratifications of the countries outside the Euro area - unlike Art. 48 TEU, which places everyone on an equal footing - and also creates a double standard between the 12 Eurozone countries that are the first to ratify and the others. $^{68}$

A second potential dismemberment is occurring, again, within the Economic and Monetary Union and, in contrast to the former, has gained much more public attention. It refers to the role taken up by the EBC since 2011 through its unconventional monetary operations to preserve the stability of the euro. Given the clear-cut division between the fully integrated monetary leg of the Economic and Monetary Union and the economic policies that are still managed at national level and just coordinated through the EU, the ECB could only protect the Eurozone against asymmetric shocks by interpreting its mandate extensively; a mandate that is conceived in very strict terms in the Treaties. It followed a strong clash between the ECB and the Court of Justice ruling in favour of the central bank (to have acted within its mandate), on the one hand, and the German Constitutional Court, on the other. ${ }^{69}$ The saga is still open at the time of writing, but, again, the problem with the ECB's mandate is that there is no unanimous consent to modify it in the Treaties to make borrowing possible as it probably should and therefore the financial support lend by this institution on the financial markets has gone too far according to its critics, $^{70}$ despite its genuine intention to "do whatever it takes to save the euro".71

Besides these recent examples, the list of "candidates" to be treated as dismemberments in EU law can be longer, should the case law of the Court of Justice be considered as a source of dismemberment. Without any explicit legal basis in the Treaties

68 CLOSA, Carlos. Moving Away from Unanimity: Ratification of the Treaty on Stability, Coordination and Governance in the Economic and Monetary Union. RECON Online Working Paper, n 2011/38, 17 Feb. 2012.

69 For the latest episode of the saga, see: German Constitutional Tribunal, Second Senate. 2 BvR 859/15 (Judgment of the Court of 5 May. 2020), which declared ultra vires the ECB's Public Sector Purchase Programme and the decision of the Court of Justice confirming its validity, pending further clarifications by the ECB as to the proportionality of its action.

70 BOBIĆ, Ana; DAWSON, Mark. COVID-19 and the European Central Bank: The Legal Foundations of EMU as the Next Victim? Verfassungsblog, 27 Mar. 2020. Available at: <https://verfassungsblog.de/covid-19-and-theeuropean-central-bank-the-legal-foundations-of-emu-as-the-next-victim/>.

71 See the famous speech by the President of the ECB, Mario Draghi, at the press conference of 6 August 2012 announcing the Outright Monetary Transaction Programme. 
foundational principles of EU law, like primacy and direct effect, ${ }^{72}$ have been identified by the Court of Justice as the grundnorm of the Union. Despite their lack of codification in EU primary law, their acknowledgement by the Court has "transformed" the nature of the European integration process compared to what had been until the 1960s. As such the conceptualization of "dismemberment" by Richard Albert can find an interesting litmus test even in the context of a sui generis constitutional constellation like the EU.

\section{CONSTITUTIONAL UNAMENDABILITY IN EU LAW}

To conclude, some final remarks can be devoted to the contribution of Richard Albert's monograph to the question of constitutional unamendability in EU law. The limits to constitutional reforms and unconstitutional constitutional amendments have come under increasing academic scrutiny. ${ }^{73}$ Perhaps democratic decay and the crisis of liberal constitutionalism have contributed to make these issues "hot topics" in comparative constitutional law. By the same token, the multiple crises the EU has experienced over the last few years and, in particular, the rule of law backsliding in Eastern Europe have made quite compelling the identification of the ultimate constitutional principles, the foundations of EU law. The debate is not new, ${ }^{74}$ but it is resurging now. ${ }^{75}$ Most Constitutions in the Member States sets explicit limits to constitutional amendments or have implicit limits, as interpreted by Courts. As such they also set the boundaries to further European integration. ${ }^{76}$

In the 1990s some scholars claimed that substantive limits to the revision of the EU Treaties were in place, for example, the respect of human rights, of the rule of law and of democratic principles. ${ }^{77}$ However, then and now the plain words of the Treaties do not offer examples of codified unamendable clauses. ${ }^{78}$ Interestingly, it has been argued that the values enshrined in Art. 2 TEU - "respect for human dignity, freedom,

\footnotetext{
72 See ft 12 above.

73 See, amongst many, ROZNAI, Yaniv. Unconstitutional Constitutional Amendments: The Limits of Amendment Powers. Oxford: Oxford University Press, 2017.

74 See, e.g., DE WITTE, B. Rules of Change in International Law: How Special is the European Community?. Netherlands Yearbook of International Law, vol. 25, p. 299 ff., Dec. 1994.

75 See: PASSCHIER, Reijer; STREMLER, Maarten. Unconstitutional Constitutional Amendments in European Union Law: Considering the Existence of Substantive Constraints on Treaty Revision. Cambridge Journal of International and Comparative Law, vol. 5, p. 337-362, Jan. 2016.

76 BESSELINK, Leonard F.M.; CLAES, Monica; IMAMOVIĆ, Šejla; REESTMAN, Jan Herman. National constitutional avenues for further integration, Study for the European Parliament. Brussels: Directorate General for Internal Policies, 2014.

77 CURTIN, Deirdre. The Constitutional Structure of the Union: A Europe of Bits and Pieces. Common Market Law Review, vol. 30, n. 1, Feb. 1993, p. 17 ff. and WEILER, Joseph H.H.; HALTERN, Ulrich. The Autonomy of the Community Legal Order: Through the Looking Glass. Harvard International Law Journal, vol. 37, n. 2, 1996, p $411 \mathrm{ff}$.

78 ALBERT, Richard. Constitutional Amendments: Making, Breaking and Changing Constitutions. Oxford: Oxford University Press, 2019, p. 140.
} 
democracy, equality, the rule of law and respect for human rights, including the rights of persons belonging to minorities", "common to the Member States in a society in which pluralism, non-discrimination, tolerance, justice, solidarity and equality between women and men prevail" - amount to foundational principles of the Union, ${ }^{79}$ but this has never been confirmed by the Court of Justice, which to date has always refused to deliver judgments grounded on this article only.

However, looking at the Court of Justice's jurisprudence there are clear signs of "interpretative unamendability" in Richard Albert's terms, ${ }^{80}$ although this Court lacks a doctrine on unconstitutional constitutional amendments. As anticipated (in section 2), the Court of Justice is the fundamental engine of the "integration though law" in the Union and many developments, in particular advancements in the way EU law has been interpreted in its relationship with the Member States are due to the fundamental role played by this Court. Up to the point that scholars have talked of a "judicial construction of Europe". ${ }^{81}$ Often accused of "judicial activism" and of monopolizing the Treaties, ${ }^{82}$ the Court of Justice, in cooperation with national courts through the preliminary reference procedure (Art. 267 TFEU), ${ }^{83}$ has let EU law evolve in a direction that could hardly be foreseen in the 1950s when it was established.

In a few landmark judgments the Court of Justice has identified some foundational rules and principles. Although were not detected in relation to Treaty revisions, they have emerged in such contexts that allowed to consider them as the ultimate rules for the functioning of the EU. In the Kadi judgment, in the framework of a potential clash between an UN Security Council's Resolution against suspect terrorists and EU law's guarantees of due process, the Court affirmed that by no means the EU could violate its commitment to rule of law and to fundamental rights' protection. ${ }^{84}$

Other important statements of the Court with regard to EU law foundational principles/rules were rendered in the framework of opinions or judgments dealing with the prospective creation of alternative judicial mechanisms or new Courts that could

\footnotetext{
79 PASSCHIER, Reijer; STREMLER, Maarten. Unconstitutional Constitutional Amendments in European Union Law: Considering the Existence of Substantive Constraints on Treaty Revision. Cambridge Journal of International and Comparative Law, vol. 5, Jan. 2016, p. 357. According to VON BOGDANDY, Armin; SPIEKER, Luke D. Countering the Judicial Silencing of Critics: Article 2 TEU Values, Reverse Solange, and the Responsibilities of National Judges. European Constitutional Law Review, vol. 15, p. 391-426, Sep. 2019 these values also represent clear constitutional limits to Member States' actions.

80 ALBERT, Richard. Constitutional Amendments: Making, Breaking and Changing Constitutions. Oxford: Oxford University Press, 2019, p. 149 ff.

81 STONE SWEET, Alec. The Judicial Construction of Europe. Oxford: Oxford University Press, 2004.

82 DAVIES, Gareth. Does the Court of Justice own the Treaties? Interpretative pluralism as a solution to overconstitutionalisation. European Law Journal, vol. 24, n. 6, p. 358-375, Nov. 2018.

83 CLAES, Monica. The National Courts' Mandate in the European Constitution Oxford-Portland: Hart Publishing, 2006.

84 European Court of Justice. Kadi and Al Barakaat v. Council. Joined Cases C-402/05 P and C-415/05 P (Judgment of the Court of 3 Sep. 2008), paras 281, 284 and 316.
} 
undermine the judicial enforcement of EU law as set in the Treaties. ${ }^{85}$ Hence in the 1991 Opinion on the treaty establishing the European Economic Area the Court considered that the treaty would have created a system of courts incompatible with the EU judicial system defined in the EU Treaties and that not even a Treaty amendment could have remedied to this clash "with the very foundation of the Community", i.e. inherent in the design and functioning of its courts. ${ }^{86} \mathrm{~A}$ similar reasoning was developed later on, when the Court of Justice was asked to review the draft agreement setting up a European patent court. ${ }^{87}$ Likewise, in the Opinion on the draft agreement on the EU accession to the ECHR and in the judgment in the Achmea case, ${ }^{88}$ the Luxembourg Court affirmed that it is not possible to dismantle the crucial relationship between the courts in the Member States and the Court of Justice, thereby hinting to the fact that the preliminary reference procedure (Art. 267 TFEU) amounts to an unamendable mechanism of EU law in that it ensures the autonomy of the Union's legal system and the consistency and uniformity of its interpretation. ${ }^{89}$

Nevertheless, it is with the Pringle judgment in $2012^{90}$ that the Court engages clearly with "interpretative unamendability". Through a preliminary reference by the Irish Supreme Court, the European Court was given the opportunity to review the compatibility of a Treaty amendment adopted under the simplified revision procedure, the already mentioned Decision EU 2011/199, with EU primary law (as well as to deal with other legal issues the remains out of the scope of this contribution). This Decision was meant to provide a legal basis in the EU Treaties, Art. 136, par. 3 TFEU, to the rescue fund set up, on a permanent basis, though an intergovernmental agreement amongst Eurozone countries, the Treaty on the ESM. The Court of Justice considered itself entitled to review the validity of Treaty amendments; a move that could not be given for granted. ${ }^{91}$ Indeed, the Commission and the European Council as well as ten intervening States claimed that the Court did not have jurisdiction under Art. 267 TFEU to check the validity of Treaty provisions. The Court seemed first to concur with this view, but then it went

85 PASSCHIER, Reijer; STREMLER, Maarten. Unconstitutional Constitutional Amendments in European Union Law: Considering the Existence of Substantive Constraints on Treaty Revision. Cambridge Journal of International and Comparative Law, vol. 5, Jan. 2016, p. 354 ff.

86 European Court of Justice. Opinion 1/91. European Free Trade Association [1991] ECR I-6079, para 71.

87 European Court of Justice. Opinion 1/09. European and Community Patents Court [2011] ECR I-1137.

88 European Court of Justice, Full Court, Opinion 2/13, of 18 December 2014, and European Court of Justice, Grand Chamber. Slovak Republic v. Achmea. Case C-284/16 (Judgment of the Court of 6 Mar. 2018).

89 MARTINICO, Giuseppe. Building Supranational Identity: Legal Reasoning and Outcome in Kadi I and Opinion 2/13 of the Court of Justice. Italian Journal of Public Law, vol. 8, n. 2, p. 260-261, 2016.

90 European Court of Justice. Thomas Pringle v. Government of Ireland. Case C- 370/12 (Judgment of the Court of 27 Nov. 2012).

91 MURPHY, Ciara. Pringle - The Unconstitutional Constitutional Amendment Conundrum. European Law Blog, Dec. 6 2012. Available at: <https://europeanlawblog.eu/2012/12/06/pringle-the-unconstitutional-constitutional-amendment-conundrum/>. 
on saying in the light of the conditions set by Art. 48, par. 6 TEU to follow a simplified revision procedure (that can only affect Part Three of the TFEU and cannot increase the EU competences), that the Court must ensure that "the law is observed in the interpretation and application of the Treaties". The Court eluded the distinction between procedural and substantive "constitutional amendment" review, but it engaged also with the latter to assess whether the European Council's Decision encroached upon monetary policy and (illegitimately) expanded the economic policy competence of the Union. In both cases the answer was negative also because the Court found that the contested Decision was not really needed for the sake of adopting the ESM Treaty. ${ }^{92}$ This case illustrates that there are also substantive limits to Treaty amendments under the simplified revision procedure, but only future developments can tell whether the Court is willing to check the compliance of these limits by Treaty amendments adopted under the ordinary revision procedure. From a legal perspective this appears possible, but it would be politically difficult given the present situation of "constructive unamendability".

\section{REFERENCES}

ACKERMAN, Bruce. Three Paths to Constitutionalism - and the Crisis of the European Union. British Journal of Political Science, vol. 45, n. 4, p. 705-714, May 2015.

ALBERT, Richard. Constitutional Amendments: Making, Breaking and Changing Constitutions. Oxford: Oxford University Press, 2019.

ALEMANNO, Alberto. Europe's Democracy Challenge: Citizen Participation in and Beyond Elections. German Law Journal, vol. 21, Special Issue n. 1, p. 35-40, Jan. 2020.

AZOULAI, Loïc. "Integration through law" and us. International Journal of Constitutional Law, vol. 14, n. 2, p. 449-463, Apr. 2016.

AZOULAI, LoÏc; BARBOU DES PLACES, Ségolène; PATAUT. Etienne (eds.). Constructing the Person in EU Law: Rights, Roles, Identities. Oxford: Hart Publishing, 2016.

BARDUTZKY, Samo. Constitutional Courts, Preliminary Rulings and the "New Form of Law": The Adjudication of the European Stability Mechanism. German Law Journal, vol. 16, n. 6, p. 17711790, Mar. 2015.

BESSELINK, Leonard F.M. A Composite European Constitution. Amsterdam: Europa Publishing, 2007.

92 For more details, see: PASSCHIER, Reijer; STREMLER, Maarten. Unconstitutional Constitutional Amendments in European Union Law: Considering the Existence of Substantive Constraints on Treaty Revision. Cambridge Journal of International and Comparative Law, vol. 5, Jan. 2016, p. 352-353. 
BESSELINK, Leonard F.M.; CLAES, Monica; IMAMOVIĆ, Šejla; REESTMAN, Jan Herman. National constitutional avenues for further integration, Study for the European Parliament. Brussels: Directorate General for Internal Policies, 2014.

BEUKERS, Thomas. Law, Practice and Convention in the Constitution of the European Union. Amsterdam, 2011. 419 p. Thesis (PhD) - Faculty of Law, University of Amsterdam.

BOBIĆ, Ana; DAWSON, Mark. COVID-19 and the European Central Bank: The Legal Foundations of EMU as the NextVictim? Verfassungsblog, 27 Mar. 2020. Availableat: <https://verfassungsblog.de/ covid-19-and-the-european-central-bank-the-legal-foundations-of-emu-as-the-next-victim/>.

BYBERG, Rebekka. The History of the Integration Through Law Project: Creating the Academic Expression of a Constitutional Legal Vision for Europe. German Law Journal, vol. 18, n. 6, p. 15311556, Nov. 2017.

CLAES, Monica. Constitutionalizing Europe at its Source: The 'European Clauses' in the National Constitutions: Evolution and Typology. Yearbook of European Law, vol. 24, n. 1, p. 81-125, Nov. 2005.

CLAES, Monica. The National Courts' Mandate in the European Constitution Oxford-Portland: Hart Publishing, 2006.

CLOSA, Carlos. Moving Away from Unanimity: Ratification of the Treaty on Stability, Coordination and Governance in the Economic and Monetary Union. RECON Online Working Paper, $\mathrm{n}^{\circ}$ 2011/38, 17 Feb. 2012.

CLOSA, Carlos. The Politics of Ratification of EU Treaties. Abingdon: Routledge, 2013.

CÓLON-RÍOS, Joel. Constituent Power and the Law. Oxford: Oxford University Press, 2020.

CRUM, Ben. Learning from the EU Constitutional Treaty: Democratic constitutionalization beyond the Nation-State. Abingdon: Routledge, 2011.

CURTIN, Deirdre. The Constitutional Structure of the Union: A Europe of Bits and Pieces. Common Market Law Review, vol. 30, n. 1, p. 17-69, Feb. 1993.

DAVIES, Gareth. Does the Court of Justice own the Treaties? Interpretative pluralism as a solution to over-constitutionalisation. European Law Journal, vol. 24, n. 6, p. 358-375, Nov. 2018.

DELOCHE-GAUDEZ, Florence. La Convention européenne sur l'avenir de l'Europe: ruptures et continuités. In: AMATO, Giuliano; BRIBOSIA, Emmanuelle and DE WITTE, Bruno (eds.). Genèse et destinée de la Constitution européenne: commentaire du traité établissant une Constitution pour l'Europe à la lumière des travaux préparatoires et perspectives d'avenir. Bruxelles: Bruylant, 2007. p. $47-85$

DE WITTE, B. Rules of Change in International Law: How Special is the European Community?. Netherlands Yearbook of International Law, vol. 25, p. 299 ff., Dec. 1994. 
DE WITTE, Bruno. The Closest Thing to a Constitutional Conversation in Europe: The Semi-Permanent Treaty Revision Process. In: BEAUMONT, Paul, LYONS, Carole and WALKER, Neil (eds.). Convergence and Divergence in European Public Law. Oxford-Portland: Hart Publishing, 2002. p. 39-58.

DE WITTE, Bruno; MARTINELLI, Thibaud. Treaties between EU Member States as Quasi-Instruments of EU Law. In: CREMONA, Marise and KILPATRICK, Claire (eds). EU Legal Acts: Challenges and Transformations. Oxford: Oxford University Press, 2018, p. 158-188.

ELEFTHERIADIS, Pavlos. The Idea of a European Constitution. Oxford Journal of Legal Studies, vol. 27, n. 1, p. 1-21, Spr. 2007

ELEFTHERIADIS, Pavlos. A Union of Peoples. Oxford: Oxford University Press, 2020.

FABBRINI, Sergio. Which European Union? Europe after the Euro Crisis. Cambridge: Cambridge University Press, 2015, p. 219-256.

FICHERA, Massimo; POLLICINO, Oreste. The Dialectics Between Constitutional Identity and Common Constitutional Traditions: Which Language for Cooperative Constitutionalism in Europe?. German Law Journal, vol. 20, n. 8, p. 1097-1118, Dec. 2019.

GERAPETRITIS, George. New Economic Constitutionalism in Europe. Oxford: Hart Publishing, 2019.

GRANAT, Katarzyna. Approval of Article 136 TFEU Amendment in Poland: The Perspective of the Constitutional Court on Eurozone Crisis law. European Public Law, vol. 21, n. 1, p. 31-46, Feb. 2015.

GRIMM, Dieter. The Democratic Costs of Constitutionalisation: The European Case. European Law Journal, vol. 21, n. 4, p. 460-473, May. 2015.

GRIMM, Dieter. Sovereignty: The Origin and Future of a Political and Legal Concept. New York: Columbia University Press, 2015.

HABERMAS, Jürgen. Democracy in Europe: Why the development of the EU into a transnational democracy is necessary and how it is possible. European Law Journal, vol. 21, n. 4, p. 546-557, Jul. 2015.

HOOGHE, Liesbet and MARKS, Gary. A Postfunctionalist Theory of European Integration: From Permissive Consensus to Constraining Dissensus. British Journal of Political Science, vol. 39, n. 1, p. 1-23, Jan. 2009.

JELLINEK, George. Allgemeine Staatslehre. 3. ed. Berlin: Häring, 1914.

IBRIDO, Renato; LUPO, Nicola. Introduzione. "Forma di governo" e "indirizzo politico": la discussa applicabilità all'Unione europea. In: IBRIDO, Renato; LUPO, Nicola (eds.). Dinamiche della forma di governo tra Unione europea e Stati membri. Bologna, II Mulino, 2018, p. 9-53. 
LENAERTS, Koen. How to Simplify the Instruments of the Union. The European Convention Working Group IX, Working Document 07, 6 Nov. 2002.

LINDSETH, Peter L. Power and Legitimacy: Reconciling Europe and the Nation State. Oxford: Oxford University Press, 2010, p. 234.

MANZELLA, Andrea. The convention: a new model for constitution-making. In: Europeos (ed.). Institutional reforms in the European Union. Rome: Europeos, 2002. p. 159-182.

MARTINICO, Giuseppe. Building Supranational Identity: Legal Reasoning and Outcome in Kadi I and Opinion 2/13 of the Court of Justice. Italian Journal of Public Law, vol. 8, n. 2, p. 260-261, 2016.

MURPHY, Ciara. Pringle - The Unconstitutional Constitutional Amendment Conundrum. European Law Blog, Dec. 6 2012. Available at: <https://europeanlawblog.eu/2012/12/06/ pringle-the-unconstitutional-constitutional-amendment-conundrum/>.

MENÉNDEZ, Agustín José; FOSSUM, John Erik (eds.). Law and Democracy in Neil MacCormick's Legal and Political Theory. New York: Springer, 2011.

NIKOLAÏDIS, Kalypso. European Demoicracy and Its Crisis. Journal of Common Market Studies, vol. 51, n. 2, p. 351-369, mar. 2013.

OKLOPCIC, Zoran. Beyond the People: Social Imaginary and Constituent Imagination. Oxford: Oxford University Press, 2018.

O'FLYNN, Ian. Deliberative Democracy and Divided Societies. Edinburgh: Edinburgh University Press, 2006, p. $32 \mathrm{ff}$.

PASSCHIER, Reijer; STREMLER, Maarten. Unconstitutional Constitutional Amendments in European Union Law: Considering the Existence of Substantive Constraints on Treaty Revision. Cambridge Journal of International and Comparative Law, vol. 5, p. 337-362, Jan. 2016.

PATBERG, Markus. A systematic justification for the EU's pouvoir constituant mixte: Principles of constitutional politics in supranational polities. European Law Journal, vol. 23, n. 6, p. 451-463, Nov. 2017.

PATBERG, Markus. Challenging the masters of the treaties: Emerging narratives of constituent power in the European Union. Global Constitutionalism, vol. 7, n. 2, p. 263-293, Jul. 2018.

PEERS, Steve. The Future of EU Treaty Amendments. Yearbook of European Law, vol. 31, n. 1, p. 19-22, Apr. 2012.

PESCATORE, Pierre. Le droit de l'integration. Emergence d'un phénomène nouveau dans les relations Internationales selon l'expérience des Communautés Européennes. Genève: A.W. Sijthoff, Leiden/Institut Universitaire de Hautes Etudes Internationales, 1972. 
PICCIRILLI, Giovanni. La clausola di sbarramento per le elezioni europee tra Corte costituzionale e principi comuni a tutti gli Stati membri. Studium Iuris, vol. 12, p. 1430-1437, 2019.

PINELLI, Cesare. The Convention Method. In: LUPO, Nicola; FASONE, Cristina (eds.). Interparliamentary Cooperation in the Composite European Constitution. Oxford-Portland: Hart Publishing, 2016. p. 57-72.

PONZANO, Paolo. The "Spinelli"Treaty of February 1984. Centro di studi sul federalismo - The Federalist Debate, vol. XX, n. 3, Nov. 2007. Available at: <http://www.federalist-debate.org/index. $\mathrm{php} /$ component/k2/item/282-the-spinelli-treaty-of-february-1984>.

ROZNAI, Yaniv. Unconstitutional Constitutional Amendments: The Limits of Amendment Powers. Oxford: Oxford University Press, 2017.

SCHARPF, Fritz W. De-constitutionalisation and majority rule: A democratic vision for Europe. European Law Journal, vol. 23, n. 5, p. 330-332, Nov. 2017.

SCHÜTZE, Robert. From Dual to Cooperative Federalism: The Changing Structure of European Law. Oxford: Oxford University Press, 2009, chapter 1.

STONE SWEET, Alec. The Judicial Construction of Europe. Oxford: Oxford University Press, 2004. VAUCHEZ, Antoine. L'union par le droit: L'invention d'un programme institutionnel pour l'Europe. Paris: Sciences Po Les Presses, 2013.

VERDUN, Amie. The Federal Features of the EU: Lessons from Canada. Politics and Governance, vol. 4, n. 3, p. 100-110, Aug. 2016.

VIOLA, Donatella Maria (ed.). Routledge Handbook of European Elections. Abingdon: Routledge, 2015.

VON BOGDANDY, Armin; SPIEKER, Luke D. Countering the Judicial Silencing of Critics: Article 2 TEU Values, Reverse Solange, and the Responsibilities of National Judges. European Constitutional Law Review, vol. 15, p. 391-426, Sep. 2019.

WEILER, Joseph H.H. The Constitution of Europe: "Do the new clothes have an emperor?" and other essays on European integration. Cambridge: Cambridge University Press, 1999.

WEILER, Joseph H.H. On the power of the Word: Europe's constitutional iconography. International Journal of Constitutional Law, n. 2 \& 3, p. 173-190, May 2005

WEILER, Joseph H.H.; HALTERN, Ulrich. The Autonomy of the Community Legal Order: Through the Looking Glass. Harvard International Law Journal, vol. 37, n. 2, 1996. 